\title{
PEMBERDAYAAN IBU-IBU PKK NAGARI SIKUCUR BARAT MELALUI PRODUKSI VIRGIN COCONUT OIL (VCO)
}

\author{
Helga Yermadona ${ }^{1}$, Femi Earnestly ${ }^{2}$, Afrijon $^{3}$, Suryani Suryani*4 ${ }^{4}$ Firdaus $^{5}$ \\ ${ }^{1,2,4}$ Universitas Muhammadiyah Sumatera Barat; J1. Pasir Kandang No. 04 Koto Tangah Padang, \\ telp 0751-4851002, fax 0751-482274 \\ ${ }^{3}$ Universitas Taman Siswa Padang; Jl. Taman Siswa No.9 Padang, telp 0751-40020, fax 0751- \\ 444170 \\ STIKes Mercubakti Jaya Padang; Jl. Jamal Jamil Pondok Kopi Siteba Padang, telp 0751-442295, \\ fax 0751-442286 \\ *E-mail: suryanimdiah@yahoo.com
}

\begin{abstract}
Women from Sikucur Barat are economically unproductive because they generally can't support their family income. Sikucur Barat produces many coconuts and is supposed to become a chance for the women to have side income and women who belong to PKK's group. In fact the family can't rely on their life from coconut since the price is getting low only Rp.1.000. It makes the people let the coconut fall down on the ground without collecting them. This condition happens because they are unable to cover the transportation fee if sold to other cities such as Padang or Pekanbaru. Besides, the people don't have knowledge on how to process the coconut becomes the highest quality product such as Virgin Coconut Oil (VCO). Based on this problem, we try to do PKM (Service for Society) by giving training how to make right VCO, branding it, and Depkes (Health Department) permit for PKK's women in Sikucur Barat village. Thus, we hope it can become a new entrepreneur to support their income and increase the knowledge and the skills of the society of PKK's group in Sikucur Barat village. We spread the questionnaires and got the result that about $89,4 \%$ of the society's income increased.
\end{abstract}

Keywords - VCO, coconut, training, Sikucur Barat.

\begin{abstract}
Abstrak
Ibu-ibu Nagari Sikucur Barat termasuk mitra tidak produktif secara ekonomi, pada umumnya adalah ibu rumah tangga yang tidak mempunyai pendapatan sendiri. Nagari Sikucur Barat sebagai daerah penghasil kelapa, seharusnya bisa dijadikan sebagai sumber pendapatan keluarga atau ekonomi bagi ibu-ibu yang tergabung dalam kelompok PKK Nagari Sikucur Barat. Tapi saat ini kelapa tidak bisa dijadikan pendapatan, karena harga jual kelapa murah sekali yaitu kurang dari Rp.1000,- per butir, sehingga buah kelapa hanya dibiarkan jatuh di kebun. Hal ini terjadi karena tidak tertutupinya biaya transportasi penjualan ke kota Padang ataupun ke kota Pekanbaru, yang merupakan tujuan penjualan. Disamping itu masyarakat tidak mempunyai pengetahuan bagaimana membuat kelapa menjadi produk yang bernilai jual tinggi seperti Virgin Coconut Oil (VCO). Maka diadakanlah kegiatan Pengabdian Kepada Masyarakat (PKM) berupa pelatihan pembuatan VCO, pembuatan merek dan pengurusan izin Depkes kepada ibu-ibu PKK Nagari Sikucur Barat sehingga menjadi suatu wirausaha baru sebagai sumber pendapatan. Pelatihan ini dapat meningkatkan pengetahuan dan keterampilan ibu-ibu PKK Nagari Sikucur Barat tentang pembuatan VCO, yang diukur melalui kuisioner mencapai peningkatan sebesar 89,4\% dan peningkatan pendapatan dari hasil penjualan VCO.
\end{abstract}

Kata kunci-VCO, kelapa, pelatihan, Sikucur Barat

\section{PENDAHULUAN}

agari Sikucur Barat merupakan nagari baru pemekaran dari Kecamatan V Koto Kampung Dalam,

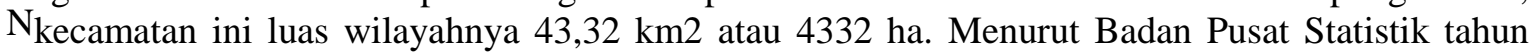


2017[1], sebanyak 1,525 ha atau 35,2\% adalah kebun kelapa, selebihnya lahan sawah 28,64\% dan $36,16 \%$ tanaman muda hortikultura seperti jagung, ubi dan pisang. Karena hasil utamanya adalah kelapa, seharusnya pendapatan masyarakatnya berasal dari kelapa, tapi saat ini harga kelapa sangat murah yaitu kurang dari Rp 1000,- per butir. Akibatnya banyak kelapa yang dibiarkan jatuh begitu saja di kebun. Penjualan kelapa ke luar daerah Sikucur Barat, tujuannya hanya Kota Padang dan Kota Pekanbaru, tapi biaya transportasinya lebih mahal daripada harga jual kelapa. Untuk membuat kelapa menjadi produk yang bernilai jual tinggi, maka kelapa diolah menjadi Virgin Coconut Oil (VCO), tetapi ibu-ibu kelompok PKK Nagari Sikucur Barat belum mengetahui dan belum memahami bagaimana cara membuat VCO [2] dari fermentasi santan kelapa[3], [4].

Nagari Sikucur Barat juga memiliki banyak lahan sawah yang ditanami padi, sehingga banyak pula masyarakat yang beternak itik. Ini dibuktikan dengan data dari Badan Pusat Statistik tahun 2017, populasi ternak unggas itik sebanyak 3728 ekor [1]. Sumber makanan itik ini biasanya hanya dedak padi, tapi bisa ditambah juga dengan makanan yang konsentrat. Sayangnya biaya untuk makanan itik seperti itu mahal, sementara harga jual telur itik murah yaitu Rp.2000,- per butir. Bila dihubungkan pembuatan VCO dengan kebutuhan makanan atau pakan itik, ternyata ampas atau limbah proses pembuatan VCO [3], dapat dijadikan makanan itik. Tapi masalahnya pengetahuan kelompok ibu-ibu PKK Nagari Sikucur Barat ini belum memadai tentang pembuatan pakan itik dari limbah VCO. Anggota tim PPM telah beberapa kali melaksanakan pemberdayaan masyarakat melalui proses pembuatan VCO, antara lain yang dilakukan pada Kelompok Ibu-ibu RT 002/RW 005 Komplek Perumahan Wisma Warta Ulak Karang Padang [5], dan pelatihan pembuatan VCO (Virgin Coconut Oil) melalui fermentasi santan secara spontan di Kelompok Ibuibu daerah Kuranji Kota Padang [6]. Sementara itu anggota tim PPM juga sudah banyak melakukan penelitian tentang pembuatannya VCO, kegunaannya maupun kandungan bakteriosin yang ada pada lapisan minyak VCO ini [7], [8], [9].

Pakan itik yang berbentuk pelet biasanya ditambahkan atau diperkaya dengan bakteri Lactobacillus salivarius[10] yang merupakan probiotik, tujuannya adalah untuk kualitas kesehatan dan meningkatkan kemampuan produksi ternak. Sementara itu pada blondo (ampas pembuatan VCO) mengandung beberapa macam bakteri asam laktat seperti Lactobacillus plantarum[8], Lactobacillus paracasei[11], dan Lactobacillus thermobacterium, sehingga bila ampas kelapa dan blondo dicampur dan diberikan sebagai pengganti makanan yang berupa konsentrat, akan menurunkan biaya pembelian pakan pada peternakan itik.

\section{METODE}

Metode yang dilakukan pada Program Pengabdian Kepada Masyarakat (PKM) ini ada dua, yaitu:

\subsection{Metode yang dipakai untuk meyelesaikan masalah}

Permasalahan yang ada pada Kelompok Ibu-ibu PKK Nagari Sikucur Barat yaitu ibu-ibu ini belum mengetahui dan belum memahami bagaimana cara membuat VCO [2] dari fermentasi santan kelapa sampai pemasarannya yang diselesaikan dengan enam tahapan yaitu:

(1) Sosialisasi VCO,

(2) Pelatihan pembuatan VCO,

(3) Pelatihan cara memanen VCO,

(4) Pengemasan produk

(5) Pembuatan merek dan izin produk, dan

(6) Pelatihan pemasaran offline maupun online, seperti terlihat pada Gambar 1 berikut ini: 


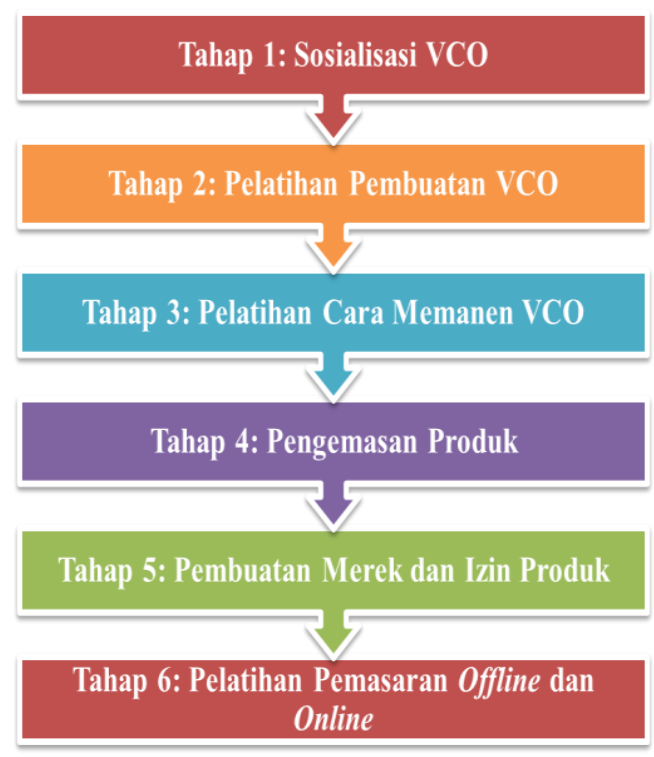

Gambar 1 Tahapan penyelesaian masalah

\subsection{Metode teknis pembuatan $\mathrm{VCO}$}

Metode teknis pembuatan VCO terdiri dari enam tahap yaitu:

(1) Pemilihan kelapa,

(2) Kelapa diparut dan dijadikan santan,

(3) Santan difermentasi,

(4) Panen setelah sehari semalam,

(5) Dikemas dalam botol, dan

(6) Pemberian merek, seperti terlihat pada Gambar 2 berikut ini:

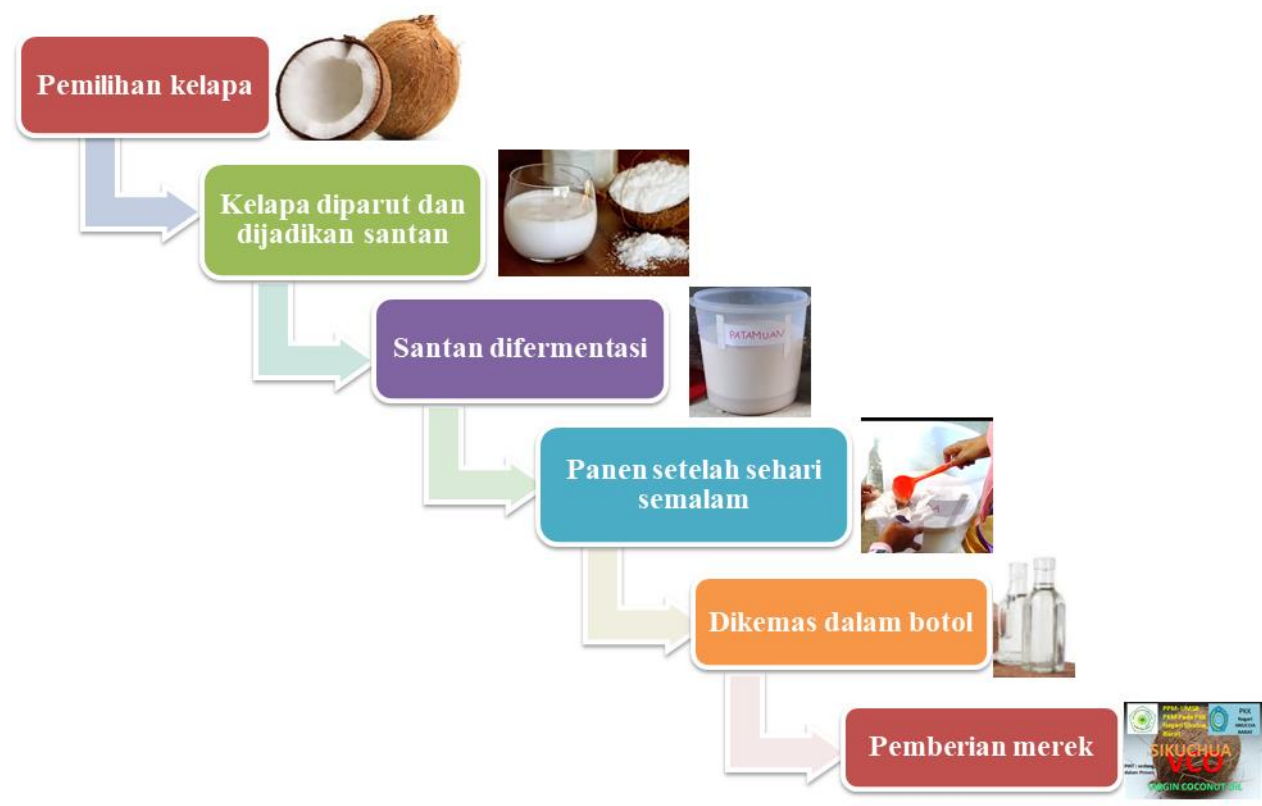

Gambar 2 Tahapan metode teknis pembuatan VCO

\section{HASIL DAN PEMBAHASAN}

Hasil pelaksanaan Program PKM pada Ibu-ibu PKK di Nagara Sikucur Barat, dilaksanakan sesuai dengan tahapan dalam menyelesaikan permasalahan yang ada yaitu: 


\subsection{Hasil Sosialisasi Virgin Coconut Oil (VCO)}

Tahap Sosialisasi dilaksanakan pada hari Senin tanggal 4 Maret 2019, dan hari Minggu tanggal 17 Maret 2019. Turut hadir pada kegiatan ini Ibu Ketua Tim Penggerak PKK Nagari Sikucua Barat, beserta pengurus lainnya dan Bapak Wali Nagari Sikucua Barat beserta jajarannya. Pada saat sosialisasi ini hadir 5 orang utusan anggota PKK setiap Korong, dimana di Nagari Sikucua ini ada 7 Korong, kegiatan sosialisasi VCO seperti terlihat pada Gambar 3 dan Gambar 4 berikut:
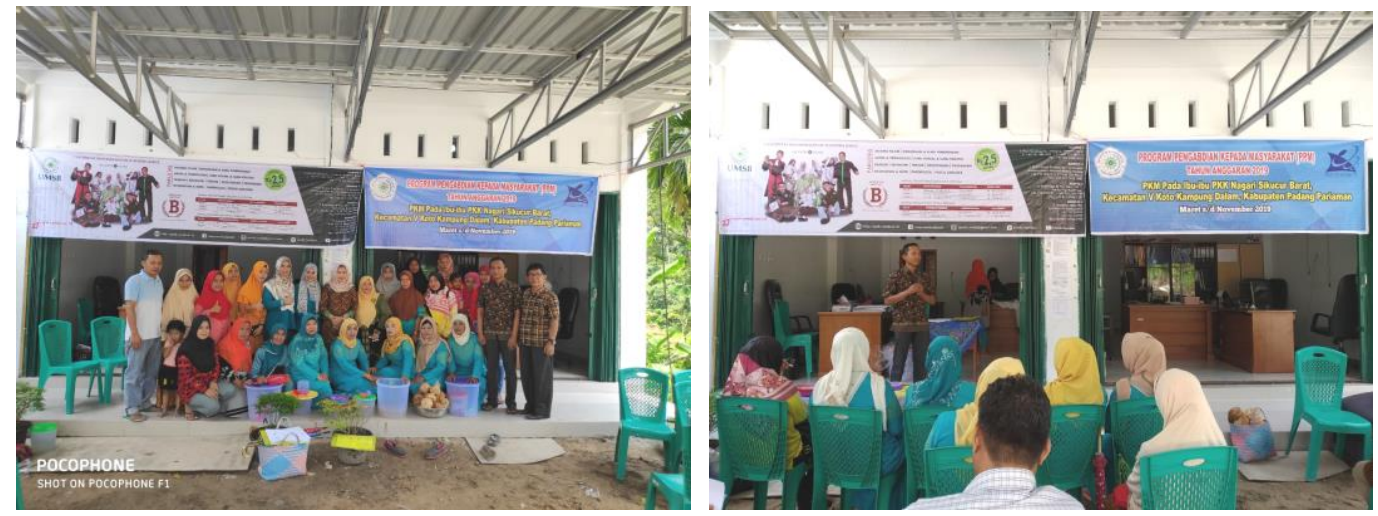

Gambar 3 Kegiatan sosialisasi VCO bersama ibu-ibu PKK Nagari Sikucur Barat

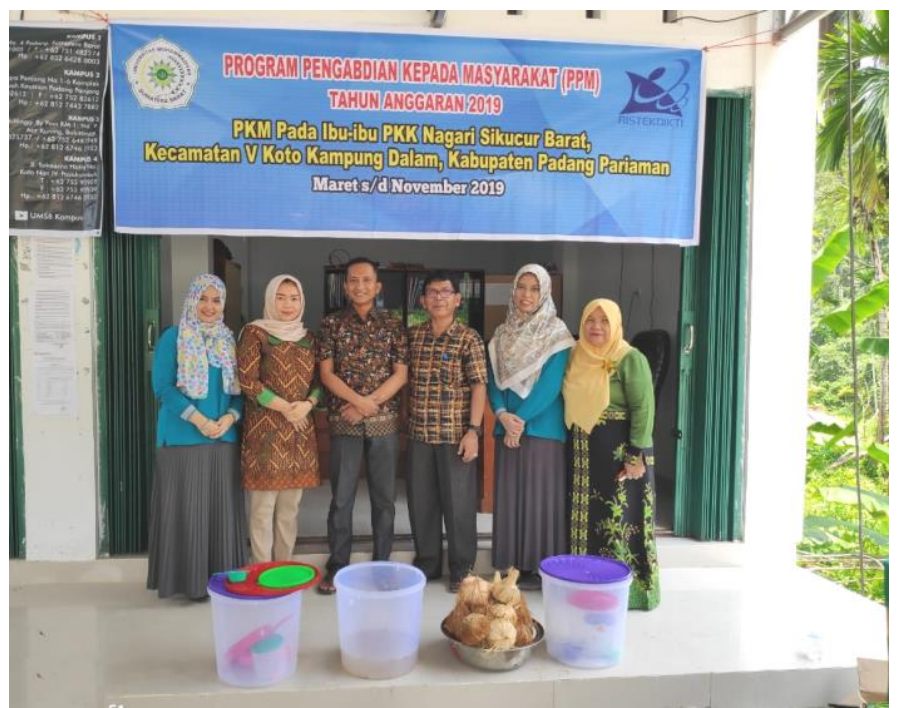

Gambar 4. Tim PPM bersama Ketua PKK dan Bapak Wali Nagari Sikucur Barat.

Sebelum sosialisasi, disebarkan kuisioner (pre-test) kepada peserta untuk mengukur pengetahuannya terhadap Virgin Coconut Oil. Kuisioner berisi 10 pertanyaan tentang VCO yang hasilnya seperti pada Tabel 1 berikut:

Tabel 1 Hasil kuisioner awal (pre-test) PKM pada ibu-ibu PKK Nagari Sikucur Barat

\begin{tabular}{|c|l|c|}
\hline No & \multicolumn{1}{|c|}{ Nama } & $\begin{array}{c}\text { Jumlah pertanyaan yang terjawab dari 10 } \\
\text { pertanyaan }\end{array}$ \\
\hline 1 & Nurlela & 5 \\
\hline 2 & Susi Susanti & 4 \\
\hline 3 & Sriwahyuni & 5 \\
\hline 4 & Nurmalini & 5 \\
\hline 5 & Resmi Asli & 4 \\
\hline 6 & Supariem & 3 \\
\hline 7 & Yarnisa & 4 \\
\hline 8 & Daminar & 5 \\
\hline
\end{tabular}




\begin{tabular}{|c|c|c|}
\hline 9 & Dasminar & 4 \\
\hline 10 & Intan & 4 \\
\hline 11 & Julpitriani & 5 \\
\hline 12 & Marianis & 5 \\
\hline 13 & Reflina Putri & 4 \\
\hline 14 & Salmiati & 3 \\
\hline 15 & Emawati & 4 \\
\hline 16 & Mayuni & 4 \\
\hline 17 & Ida Murni & 5 \\
\hline 18 & Efi Oktavia & 4 \\
\hline \multicolumn{2}{|c|}{$\begin{array}{c}\text { Rata-rata nilai kuisioner (pre- } \\
\text { test) }\end{array}$} & $4,28 \times 100 \%=42,8 \%$ \\
\hline
\end{tabular}

Pada Tabel 1 terlihat bahwa pengetahuan peserta masih sangat minim dengan rata-rata pertanyan yang terjawab hanya $42,8 \%$. Setelah disebarkan kuisioner, tahap selanjutnya adalah pelatihan pembuatan VCO. Setelah sosialisasi dan pelatihan VCO, peserta kembali mengisi kuisioner akhir (post-test) untuk mengukur peningkatan pengetahuannya tentang VCO yang hasilnya bisa dilihat pada Tabel 2 berikut ini:

Tabel 2 Hasil kuisioner akhir (post-test) PKM pada ibu-ibu PKK Nagari Sikucur Barat

\begin{tabular}{|c|l|c|}
\hline No & \multicolumn{1}{|c|}{ Nama } & $\begin{array}{c}\text { Jumlah pertanyaan yang terjawab dari 10 } \\
\text { pertanyaan }\end{array}$ \\
\hline 1 & Nurlela & 10 \\
\hline 2 & Susi Susanti & 8 \\
\hline 3 & Sriwahyuni & 9 \\
\hline 4 & Nurmalini & 8 \\
\hline 5 & Resmi Asli & 9 \\
\hline 6 & Supariem & 8 \\
\hline 7 & Yarnisa & 8 \\
\hline 8 & Daminar & 10 \\
\hline 9 & Dasminar & 9 \\
\hline 10 & Intan & 8 \\
\hline 11 & Julpitriani & 10 \\
\hline 12 & Marianis & 9 \\
\hline 13 & Reflina Putri & 9 \\
\hline 14 & Salmiati & 8 \\
\hline 15 & Emawati & 9 \\
\hline 16 & Mayuni & 9 \\
\hline 17 & Ida Murni & 10 \\
\hline 18 & Efi Oktavia & 10 \\
\hline \multicolumn{2}{|c|}{ Rata-rata nilai kuisioner $($ post- } & $\mathbf{8 , 9 4} \mathbf{~ 1 0 0 \%}=\mathbf{8 9 , 4 \%}$ \\
\hline \multicolumn{2}{|c|}{ test $)$} & \\
\hline
\end{tabular}

Pada Tabel 2 dari hasil pengukuran kuisioner akhir (post-test), tingkat pemahaman peserta terhadap VCO yang diberikan setelah dilakukan sosialisai beberapa kali. Peserta dapat menjawab hampir seluruh pertanyaan, pengetahuan peserta meningkat menjadi $89,4 \%$.

\subsection{Hasil Pelatihan Pembuatan VCO}

Pada tahap pelatihan pembuatan VCO ini, alat yang diperlukan untuk pembuatan VCO dibagikan kepada kelompok Ibu-ibu PKK yaitu: alat pemarut kelapa, wadah fermentasi, wadah penyimpan minyak VCO hasil panen, wadah untuk mengukur volume air yang akan digunakan memeras santan maupun untuk mengukur volume minyak hasil panen, penyaring santan dan 
sendok plastik. Kegiatan pelatihan VCO ini dilakukan beberapa kali sampai ibu-ibu ini mahir membuat sendiri dapat dilihat suasana pelatihan pembuatan VCO seperti Gambar 5 berikut:
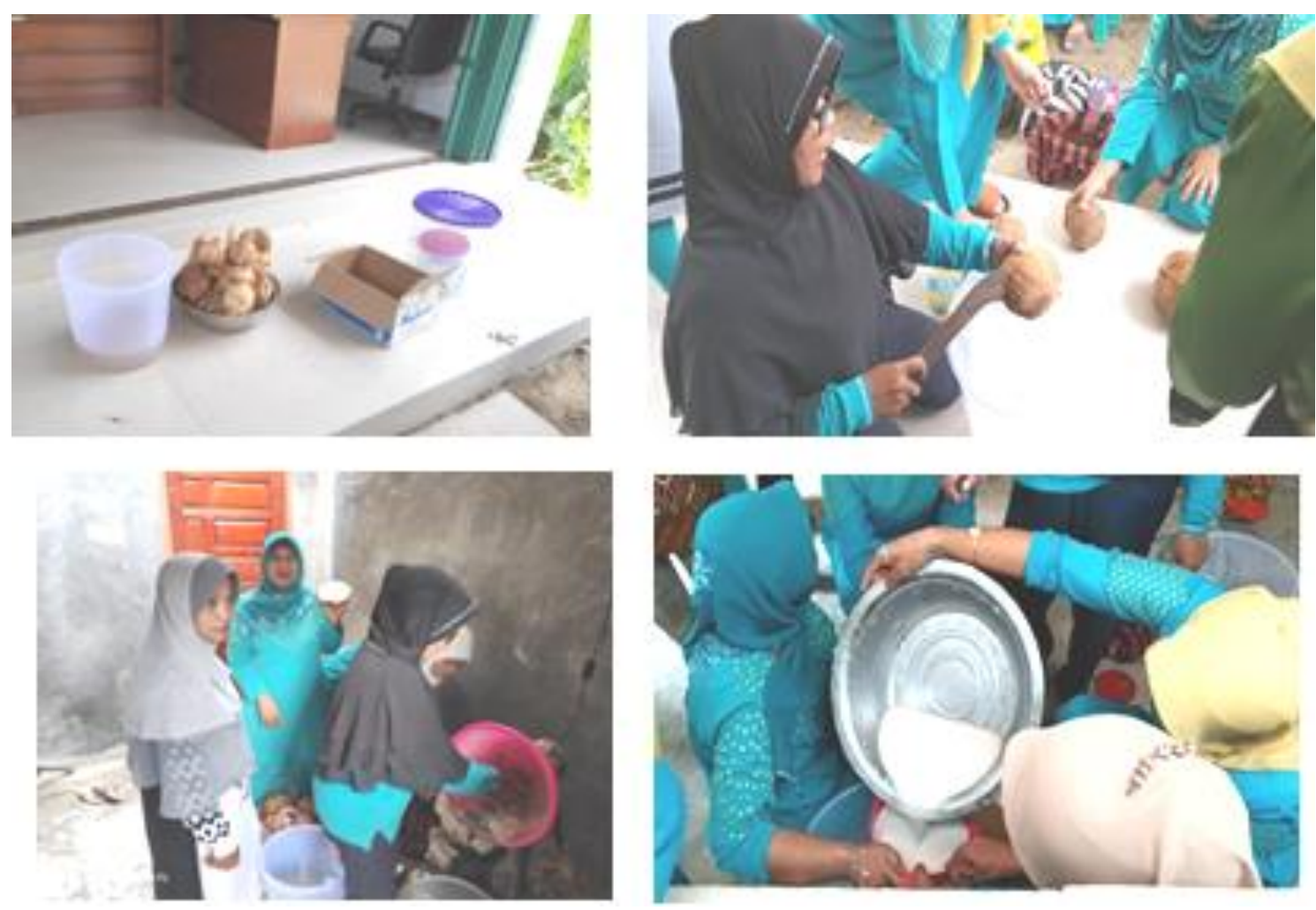

Gambar 5. Suasana pelatihan pembuatan VCO

\subsection{Hasil Pelatihan Cara Memanen VCO}

Setelah dilatih bagaimana cara membuat VCO, ibu-ibu PKK ini dilatih bagaimana cara memanen hasil VCO dari santan yang telah difermentasikan sehari semalam, dimana minyak yang dihasilkan akan terdapat pada lapisan atas dan minyak diambil dengan sendok plastik, karena tidak boleh menggunakan sendok yang terbuat dari logam. Dilakukan dua kali penyaringan supaya didapatkan VCO yang bersih dan jernih menggunakan penyaring plastik yang dilapisi kertas tisu seperti pada Gambar 6, 7, dan 8 berikut:

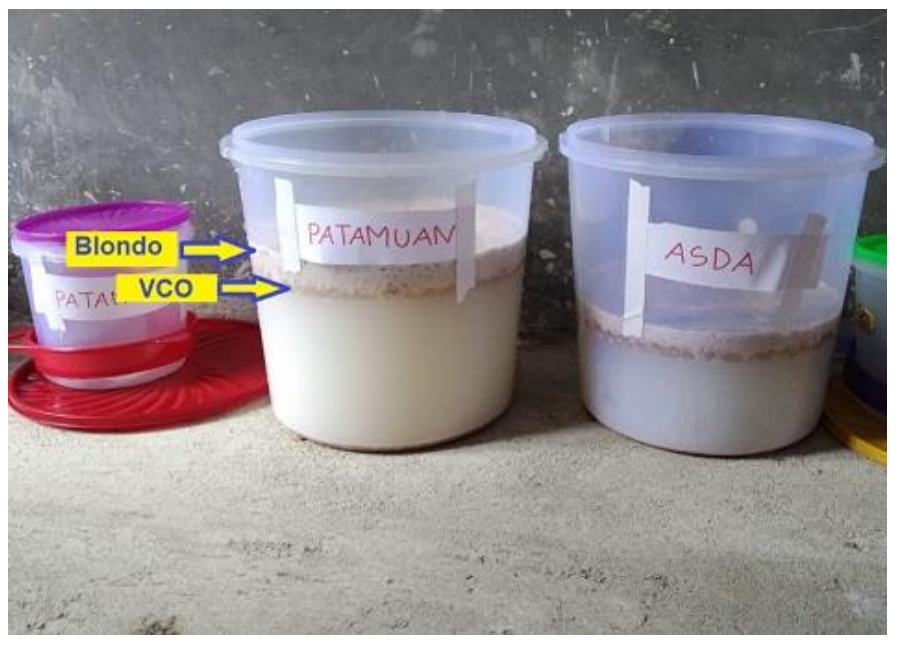

Gambar 6 Santan yang telah difermentasikan 


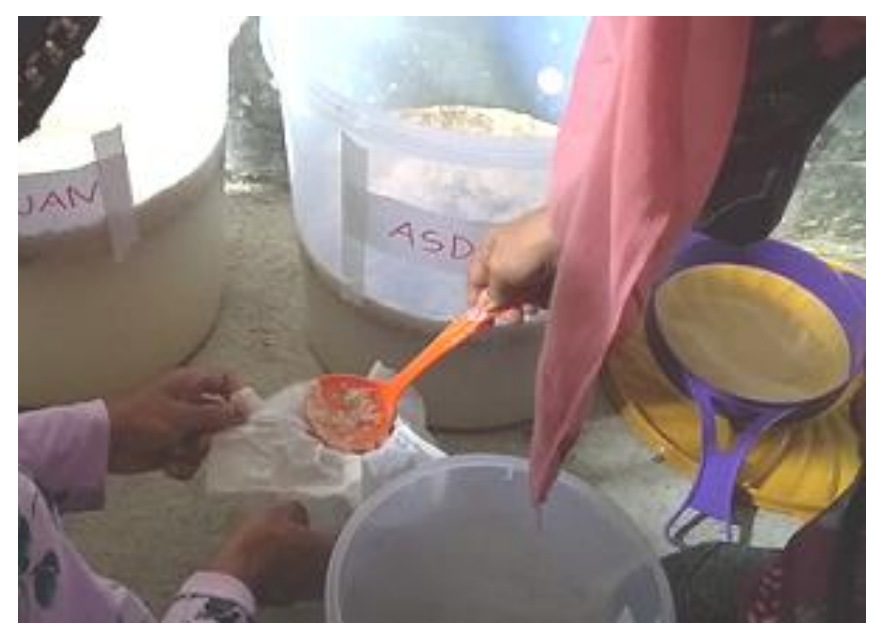

Gambar 7 Proses memanenan dan menyaring VCO

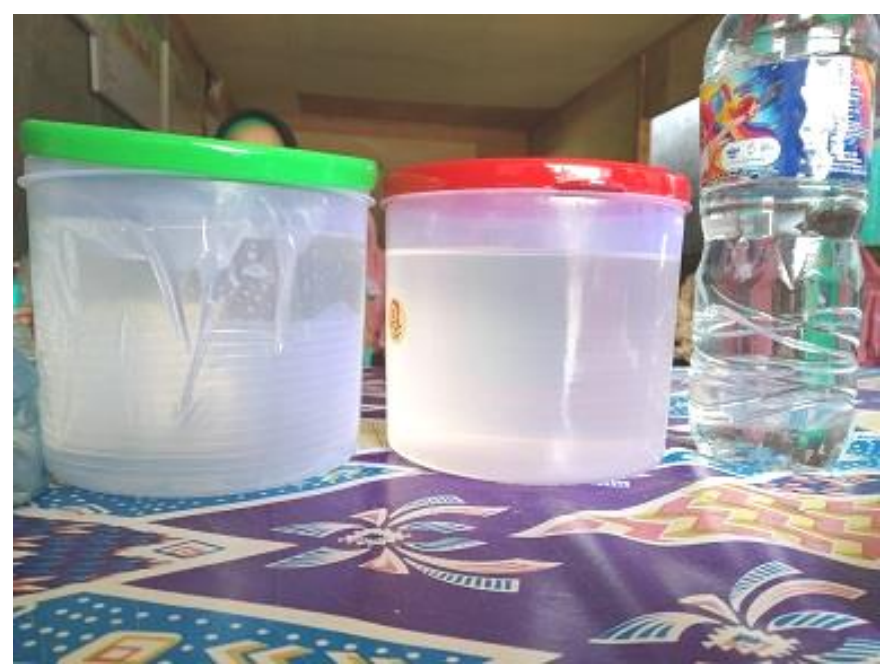

Gambar 8 Hasil panen VCO

\subsection{Hasil Pengemasan Produk VCO}

VCO dikemas dalam botol plastik transparan, supaya terlihat hasil yang jernih, dan beningnya warna VCO menandakan kualitasnya yang bagus. Ukuran botol berisi $100 \mathrm{ml}$ supaya mudah menghitung jumlah produksi, bila 10 botol berarti 1 liter, bila 17 liter berarti ada 170 botol ukuran $100 \mathrm{ml}$, karena harga penjualannya berkisar Rp. 35.000 sampai Rp.45.000 pebotol. VCO yang sudah dikemas dapat dilihat pada Gambar 9 berikut:

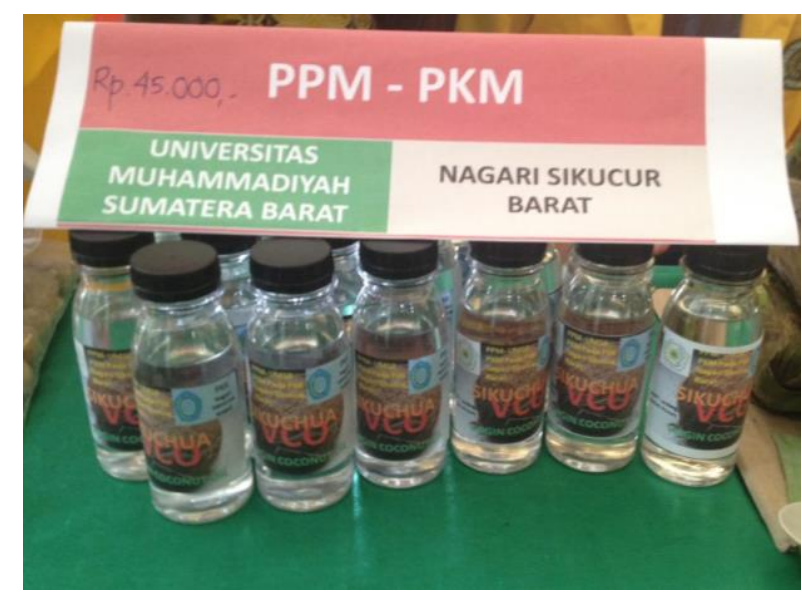

Gambar 9 VCO yang sudah dikemas 


\subsection{Hasil Pembuatan Merek}

Merek VCO hasil PPM Tim dari Universitas Muhammadiyah Sumatera Barat pada kelompok Ibu-ibu PKK Nagari Sikucur Barat ini, memuat logo Universitas Muhammadiyah Sumatera Barat dan Logo PKK Sikucur Barat, dimana Merek nya adalah "VCO Sikuchua" seperti yang dapat dilihat pada Gambar 10 berikut:

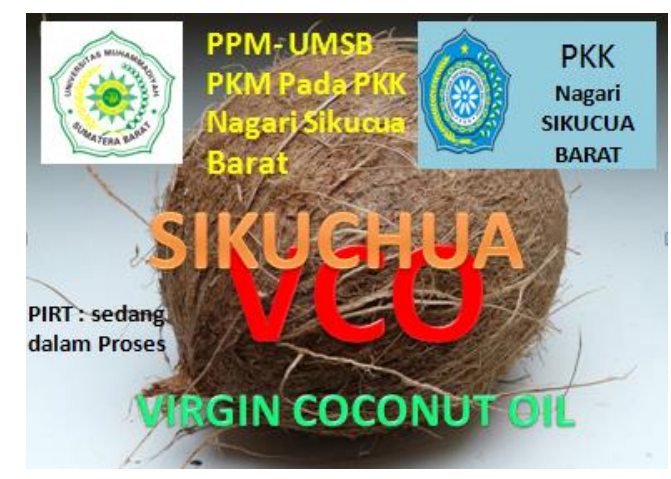

Gambar 10 Merek VCO ibu-ibu PKK Sikucua Barat.

\subsection{Hasil Pelatihan Pemasaran Baik Offline Maupun Online}

Untuk pemasaran offline dan online, ibu-ibu ini dilatih dengan memberikan pengetahuan tentang pemasaran oleh nara sumber dari tim PPM-PKM. Praktek pemasaran dilakukan dengan membawa salah seorang anggota kelompok ini ke acara, seperti pada saat kegiatan seminar, kuliah umum maupun pameran-pameran. Dengan mendaftarkan kelompok usaha ibu-ibu ini ke dinas terkait yaitu Dinas Koperindag, maka ibu-ibu ini akan mendapatkan kesempatan turut aktif ke berbagai pameran untuk pemasaran produk VCOnya, seperti pada Gambar 11 berikut:

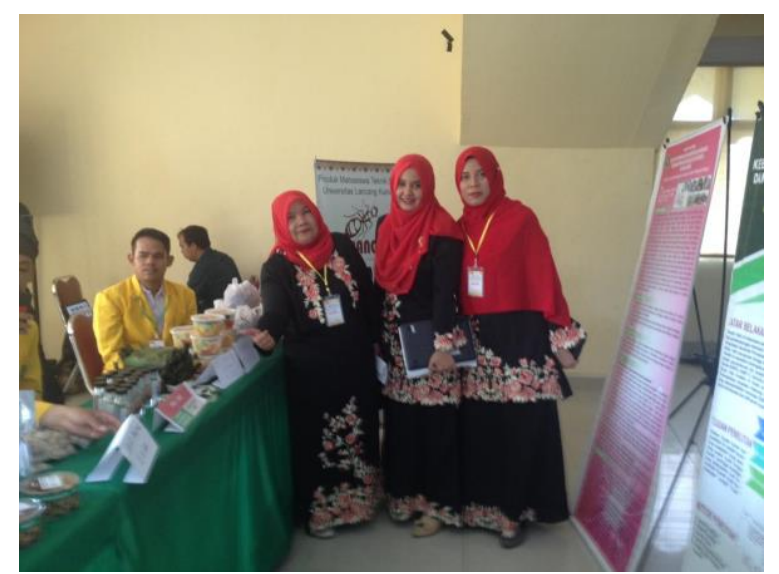

Gambar 11 Pameran produk VCO Sikucua Barat saat kegiatan seminar di Pekanbaru

Bila dibandingkan dengan program pengabdian tentang VCO yang lain [6], [5], maka pelatihan pembuatan VCO pada PPM - PKM pada ibu-ibu PKK Nagari Sikucua Barat, lebih sempurna dan lebih maksimal, karena pada yang lain itu hanya ada pelatihan pada masyarakat saja bukan pemberdayaan atau peningkatan kapasitas. PKM yang dilaksanakan Suryani 2017 dan 2016 tidak melalui tahapan - tahapan (1) Sosialisasi VCO, (2) Pelatihan pembuatan VCO, (3) Pelatihan cara memanen VCO, (4) Pengemasan produk (5) Pembuatan merek dan izin produk, dan (6) Pelatihan pemasaran offline maupun online, melainkan hanya tahap sosialisasi sampai praktek pembuatan VCO serta panen VCO. Pada program yang dilaksanakan Suryani 2016 dan 2017 tidak dengan tahapan yang lengkap sampai dengan Pelatihan pemasaran, sehingga offline maupun online, maka masyarakat hanya pandai membuat atau memproduksi, tidak pandai menjual akhirnya tidak tercapai pemberdayaan masyarakat. Berbeda sekali dengan yang dilaksnakan pada ibu-ibu PKK Sikucur Barat ini, mereka didampingi sampai mereka pandai memasarkan sendiri, sehingga tercapai pemberdayaan msyarakat. 


\section{KESIMPULAN}

Berdasarkan hasil-hasil yang diperoleh selama kegiatan PKM, kelebihan dan kekurangannya, serta kemungkinan pengembangan selanjutnya, ini dapat disimpulkan sebagai berikut:

1. Dari hasil sosialisasi pembuatan VCO, pengetahuan ibu-ibu PKK Nagari Sikucur Barat tentang VCO ini awalnya hanya 42,8\% kemudian meningkat menjadi $89,4 \%$.

2. Dari hasil pelatihan pembuatan VCO, ibu-ibu PKK Nagari Sikucur Barat mampu mempraktekkan langkah-langkah pembuatan VCO, mulai dari pemilihan kelapa, memarut kelapa, membuat santan sampai memanen VCO. Pada praktek awal, ada satu kelompok peserta yang gagal panen karena pemilihan kelapa yang kurang bagus, tetapi mereka tidak patah semangat dan mencobanya lagi pada pelatihan berikutnya sampai berhasil.

3. Dari hasil pelatihan cara memanen VCO, ibu-ibu PKK Nagari Sikucur Barat berhasil mempraktekkan cara memanen VCO dan menyaringnya hingga dua kali penyaringan menggunakan penyaring plastik dan tisu sehingga didapatkan hasil VCO yang jernih sebanyak 1 liter dari 15 butir kelapa berukuran sedang.

4. Hasil pengemasan produk VCO, ibu-ibu PKK Nagari Sikucur Barat mampu mengemas produk VCOnya kedalam botol bening ukuran $100 \mathrm{ml}$.

5. Didapatkan hasil pembuatan merek "VCO Sikuchua" yang memuat logo Universitas Muhammadiyah Sumatera Barat dan Logo PKK Sikucur Barat. Pembuatan merek ini dicetak pada kertas stiker yang nantinya ditempelkan pada botol berisi VCO.

6. Hasil pelatihan dan pemasaran offline maupun online, ibu-ibu PKK Nagari Sikucur Barat mampu memasarkan produk VCOnya diberbagai acara, sehingga terbentuk wirausaha baru yang memberikan dampak ekonomi terhadap peningkatan pendapatan keluarga.

\section{SARAN}

Saran-saran untuk untuk pengabdian lebih lanjut yaitu:

1. Diharapkan kegiatan ini dapat dilanjutkan kepada ibu-ibu nagari lain yang ada di Kecamatan V Koto Kampung Dalam, sehingga produk VCO ini dapat menjadi produk unggulan kecamatan.

2. Diharapkan setelah penjualan produk VCO dapat berlanjut terbentuknya Koperasi Unit Desa (KUD) atau Badan Usaha Milik Desa (BUMD) atau Koperasi Produk VCO.

3. Diharapkan limbah ampas kelapa dan limbah hasil VCO (blondo) dapat dimanfaatkan sebagai pakan ternak itik dan telur itik diolah menjadi telur asin

\section{UCAPAN TERIMA KASIH}

Program Pengabdian pada Masyarakat ini banyak mendapat bantuan dari berbagai pihak, oleh karena itu diucapkan terimakasih kepada:

1. Kepada Kemenristekdikti melalui DRPM yang telah membiayai kegiatan pengabdian ini.dengan Pembiayaan DRPM tahun 2019 dengan No SPK 114: SP2H/PM/DRPM/111/2019.tanggal 5 Desember 2018.

2. Bapak Wali Nagari Sikucur Barat beserta staf.

3. Ibu Ketua PKK Nagari Sikucur Barat

4. Dinas Koperindang Kabupaten Padang Pariaman.

5. Anggota PKK Nagari Sikucur Barat

\section{DAFTAR PUSTAKA}

[1] B. P. S. K. P. Pariaman, Kecamatan V Koto Kampung Dalam Dalam Angka. Pariaman: BPS Kabupaten Padang Pariaman, 2017.

[2] G. K. a G, G. Raj, A. S. Bhatnagar, P. K. P. K, and P. Chandrashekar, "Coconut Oil: Chemistry , Production and Its Applications - A Review," Indian Coconut J., pp. 15-27, 2010.

[3] D. D. Bawalan, Processing Manual for Virgin Coconut Oil, its Products and By-products for Pacific Island Countries and Territories. 2011. 
[4] S. Djajasoepena, O. Suprijana, and M. Resmelia, "Virgin coconut oil production by fermentation using Saccharomyces cerevisiae," vol. 2011, no. November, p. 19413, 2011.

[5] S. Suryani Suryani, "Pelatihan Pembuatan VCO (Virgin Coconut Oil ) Melalui Fermentasi Santan Secara Spontan DI Kelompok Ibu-Ibu daerah Kuranji KOTA PADANG,” 2017.

[6] Suryani Suryani, Wedy Nasrul, "PELATIHAN PEMBUATAN VCO (VIRGIN COCONUT OIL ) MELALUI FERMENTASI SANTAN SECARA SPONTAN DI KELOMPOK IBUIBU DAERAH KURANJI KOTA PADANG,” 2016.

[7] Suryani, A. Dharma, Y. Manjang, S. Arief, E. Munaf, and N. Nasir, "Antimicrobial and Antifungal Activity of Lactic Acid Bacteria Isolated from Coconut Milk Fermentation .," Res. J. Pharm., Biol. Chem. Sci., vol. 5, no. 6, pp. 1587-1595, 2014.

[8] S. A. Suryani, Abdi Dharma, "Isolation and Characterization of Bacteriocins Bacteria Lactobacillus Plantarum Strain NM178-5 from Fermentation Process which Contained on Coconut Milk," Transylvanian Rev., vol. XXIV, no. 6, 2016.

[9] S. Suryani, A. Dharma, and N. Nasir, "ISOLATION AND IDENTIFICATION OF PATHOGENIC BACTERIA SECRETION OF CHRONIC SUPPURATIVE OTITIS MEDIA PATIENTS," Rasayan J. Chem., vol. 11, no. 3, pp. 1139-1143, 2018.

[10] S. Sumarsih, B. Sulistiyanto, and U. Atmomarsono, "Kualitas Fisik Pakan Lengkap Itik Bentuk Pelet yang Diperkaya Lactoballius salivarius," in Seminar Nasional Tentang Unggas Lokal V, 2015, no. November, pp. 18-19.

[11] M. Suryani, Abdi Dharma, Dedi Nofiandi, Husni, "IDENTIFIKASI MOLEKULAR BAKTERI ASAM LAKTAT Lactobacillus paracasei YANG ADA PADA LAPISAN MINYAK VCO," Katalisator, vol. 2, no. 2, pp. 79-87, 2017. 